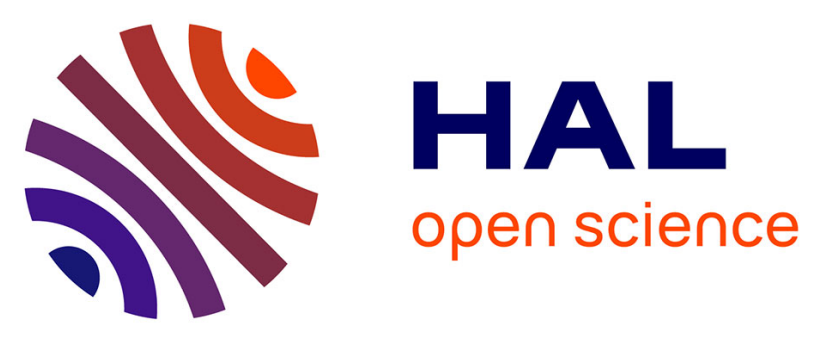

\title{
Simultaneous analysis of oxygenated and nitrated polycyclic aromatic hydrocarbons on standard reference material 1649a (urban dust) and on natural ambient air samples by gas chromatography-mass spectrometry with negative ion chemical ionisation
}

Alexandre Albinet, Eva Leoz-Garziandia, Hélène Budzinski, Eric Villenave

\section{To cite this version:}

Alexandre Albinet, Eva Leoz-Garziandia, Hélène Budzinski, Eric Villenave. Simultaneous analysis of oxygenated and nitrated polycyclic aromatic hydrocarbons on standard reference material 1649a (urban dust) and on natural ambient air samples by gas chromatography-mass spectrometry with negative ion chemical ionisation. Journal of Chromatography A, 2006, 1121 (1), pp.106-113. 10.1016/j.chroma.2006.04.043 . ineris-00961902

HAL Id: ineris-00961902

https://hal-ineris.archives-ouvertes.fr/ineris-00961902

Submitted on 20 Mar 2014

HAL is a multi-disciplinary open access archive for the deposit and dissemination of scientific research documents, whether they are published or not. The documents may come from teaching and research institutions in France or abroad, or from public or private research centers.
L'archive ouverte pluridisciplinaire HAL, est destinée au dépôt et à la diffusion de documents scientifiques de niveau recherche, publiés ou non, émanant des établissements d'enseignement et de recherche français ou étrangers, des laboratoires publics ou privés. 


\title{
Simultaneous analysis of oxygenated and nitrated polycylic aromatic
} hydrocarbons on standard reference material 1649a (urban dust) and on natural ambient air samples by gas chromatography-mass spectrometry with negative ion chemical ionisation

\author{
A. Albinet ${ }^{a^{*}}$, E. Leoz-Garziandia $^{\mathrm{a}^{*}}$, H. Budzinski ${ }^{\mathrm{b}}$, E.Villenave $^{\mathrm{c}}$ \\ ${ }^{a}$ Institut National de l'Environnement industriel et des RISques (INERIS), Parc technologique Alata BP2, 60550 \\ Verneuil en Halatte, France \\ ${ }^{b}$ Laboratoire de Physico-\& Toxico Chimie des systèmes naturels (LPTC), UMR 5472 CNRS, Université Bordeaux 1, \\ 33405 Talence, France \\ ${ }^{c}$ Laboratoire de Physico-Chimie Moléculaire (LPCM), UMR 5803 CNRS, Université Bordeaux 1, 33405 Talence, \\ France \\ * Corresponding authors. Fax : +33 344556302 \\ E-mail addresses: alexandre.albinet@gmail.com (A. Albinet), eva.leoz@ineris.fr (E.Leoz-Garziandia).
}

\begin{abstract}
This study deals with the development of a routine analytical method using gas chromatographymass spectrometry with negative ion chemical ionisation (GC/NICI-MS) for the determination of 17 nitrated polycylic aromatic hydrocarbons (NPAHs) and 9 oxygenated polycylic aromatic hydrocarbons (OPAHs) present at low concentrations in the atmosphere. This method includes a liquid chromatography purification procedure on solid phase extraction (SPE) cartridge. Application of this analytical procedure has been performed on standard reference material (SRM 1649a: urban dust), giving results in good agreement with the few data available in the literature. The analytical method was also applied on ambient air samples (on both gas and particulate phases)
\end{abstract}


from the French POVA program (POllution des Vallées Alpines). NPAHs concentrations observed for a rural site during the Winter period are about $0.2-100.0$ pg.m ${ }^{-3}$ in the particulate phase and about $0.0-20.0 \mathrm{pg} \mathrm{m}^{-3}$ in the gas phase. OPAHs present concentrations 10 to 100 times higher (0.1$2.0 \mathrm{ng} \mathrm{m}^{-3}$ and $0.0-1.4 \mathrm{ng} \mathrm{m}^{-3}$ for the particulate and the gas phases, respectively). These preliminary results show a good correlation between the characteristics of the sampling site and the compound origins (primary or secondary).

Keywords: Polycyclic aromatic hydrocarbons; Nitrated polycyclic aromatic hydrocarbons; Oxygenated polycyclic aromatic hydrocarbons; Standard reference material; Gas chromatographymass spectrometry; Negative ion chemical ionisation; Atmospheric pollution

\section{Introduction and objectives}

PAHs (polycyclic aromatic hydrocarbons) are widespread pollutants. They are emitted in the atmosphere by all the combustion sources and they are both present in the particulate and the gas phases. They have been particularly studied due to their potential carcinogenic and/or mutagenic properties [1]. Both the United States Environment Protection Agency (EPA) and the European Environment Agency now focus on sixteen of them as priority pollutants [2,3].

Oxidation PAHs products, such as NPAHs (nitrated PAHs) and OPAHs (oxygenated PAHs), seem to be more toxic than their related parent PAHs. NPAHs are formed either by nitration during combustion processes or, in the atmosphere, by both gas and heterogeneous phase reactions of PAHs with nitrogen oxides initiated by $\mathrm{OH}^{\bullet}$ or $\mathrm{NO}_{3}{ }^{\bullet}[4-11]$. Similarly to NPAHs, OPAHs are formed either directly during combustion, or by chemical reaction (photo-oxidation) initiated by oxygenated atmospheric oxidants $\left(\mathrm{OH}^{\bullet}, \mathrm{O}_{3} \ldots\right)$ [12,13]. Some of these PAHs derivatives had been identified as having a direct mutagenic potency, contrary to PAHs which require a preliminary enzymatic activation, yielding their high toxicity [14-17]. Their contribution to the mutagenicity of 
the ambient air particulate total extract was estimated to be about 50\%, using the Ames test (mutagenicity on bacteria) $[14,18,19]$. However, up to $40 \%$ of the mutagen potential was attributed to NPAHs and more specifically to nitropyrene, dinitropyrene and nitrohydroxypyrene [14]. Even though the mutagenicity of OPAHs appear less important on human cells than B[a]P [20,21], their relative high atmospheric concentrations (about $1 \mathrm{ng} \mathrm{m}^{-3}$ in the particulate phase) is of primary interest [22-24].

As a result of analytical time consuming and cost, only few data have been reported on the distribution of such compounds in the atmosphere. Unlike PAHs, analyses of PAHs oxidation products generally require several purification and pre-concentration steps. It is particularly true for NPAHs which are present in very low concentrations in the atmosphere (about $100 \mathrm{pg} \mathrm{m}^{-3}$ in the particulate phase for the most abundant compounds). Furthermore, no certified values exist for this class of compounds in the National Institute of Standards and Technology (NIST) standard reference materials (SRM). Very few studies propose NPAHs concentrations for diesel particulate extract (SRM 1975), diesel particulate matter (SRM 1650a), diesel particulate matter (industrial fortlift) (SRM 2975) and urban dust (SRM 1649a) [25-28]. To our knowledge, only three articles report OPAHs concentrations for SRM 1649a (urban dust) and only for quinones [21, 28, 29]. No data exist for the other SRM.

The objective of this study was to develop a routine analytical method for the simultaneous quantitative determination of NPAHs and OPAHs in complex environmental matrices, using GC/NICI-MS and to apply this method to the analysis of SRM 1649a (urban dust) and natural ambient air samples (for both gaseous and particulate phases). In order to minimize interferences of polar compounds, a liquid chromatography purification procedure on SPE (solid phase extraction) cartridge was applied prior to GC/MS analysis. 


\section{Experimental}

\subsection{Chemicals}

HPLC-grade quality solvents were used. Dichloromethane was purchased from Carlo Erba SDS (Peypin, France). Isooctane and n-pentane were from Aldrich (St-Quentin Fallavier, France).

The OPAHs quantified in this study were supplied by Acros Organics, Noisy le Grand, France (1-naphthaldehyde, 9-fluorenone, 9,10-anthraquinone, benzanthrone and benz[a]anthracen-7,12dione), Aldrich, St-Quentin Fallavier, France (phenanthren-9-carboxaldehyde) and Chiron, Trondhein, Norway (1,4-anthraquinone, benzo[a]fluoren-11-one, benzo[b]fluoren-11-one).

NPAHs were purchased from Carlo Erba SDS, (2-nitrofluoranthene), Acros Organics, Noisy le Grand, France (1-nitronaphthalene, 6-nitrochrysene), Aldrich, St-Quentin Fallavier, France (9nitroanthracene), Chiron, Trondhein, Norway (2-nitropyrene, 4-nitropyrene, 1,8-dinitropyrene) and Dr. Ehrenstorfer GmbH, Augsburg, Germany (2-nitronaphthalene, 2-nitrofluorene, 3nitrofluranthene, 9-nitrophenanthrene, 3-nitrophenanthrene, $\quad$ 1-nitropyrene, $\quad$ 7nitrobenz[a]anthracene, 1,3-dinitropyrene, 1,6-dinitropyrene and 6-nitrobenzo[a]pyrene). These chemicals were used to prepare calibration standards for the determination of response factors.

Deuterium labelled NPAHs from Chiron, Trondhein, Norway $\left(\left[{ }^{2} \mathrm{H}_{9}\right] 2\right.$-nitrofluorene, $\left[{ }^{2} \mathrm{H}_{9}\right] 3-$ nitrofluoranthene and $\left[{ }^{2} \mathrm{H}_{9}\right] 6$-nitrochrysene) and CDN Isotopes, Pointe-Claire, Canada (Quebec) ( $\left[{ }^{2} \mathrm{H}_{9}\right] 1$-nitronaphthalene) were used as internal standards.

SRM1649a, a reissue of SRM1649 with updated certified and reference concentration values, was prepared from atmospheric particulate material collected in the Washington-DC area in the late 1970s, using a baghouse collector specially designed for this purpose [30]. Detailed information on the sample collection and preparation have already been detailed in a previous paper [31].

Ambient air samples come from the sampling campaigns of the French POVA program (POllution des Vallées Alpines). Details of the sampling campaigns are fully described in the reference [32]. Briefly, samples have been collected for two weeks during the Winter 2002-2003 
and the Summer 2003 in two French alpine valleys (Chamonix and Maurienne valleys) after the reopening of the "Tunnel du Mont Blanc” to international traffic (which was closed during 3 years after a large accident on March 1999). Both ambient air particulate (on quartz filter) and gas (on PUF polyurethane foams) phases were sampled using modified high volume samplers equipped with $\mathrm{PM}_{10}$ head (Megatec Digitel DA-80, $30 \mathrm{~m}^{3} \mathrm{~h}^{-1}$ ) in order to determine parent PAHs and PAHs derivative concentrations. Results on PAHs concentrations and details on the analytical procedure used for their analysis (HPLC with fluorescence/UV detection) are presented elsewhere [33].

\subsection{Extraction and purification}

Filters and SRM 1649a urban dust material (approximately $100 \mathrm{mg}$ or $50 \mathrm{mg}$, 3 replicates of each) were extracted by pressurised liquid extraction (PLE; Dionex trade name ASE for accelerated solvent extraction) with a Dionex ASE 200 system. PUFs were extracted using Dionex ASE 300 system. In both cases, dichloromethane was used as extraction solvent. ASE 200 program parameters were: temperature at $120^{\circ} \mathrm{C}$, pressure at 140 bars, heat time at 6 min and static time at 6 min, for 3 cycles. ASE 300 program parameters were: temperature at $90{ }^{\circ} \mathrm{C}$, pressure at 100 bars, heat time at $5 \mathrm{~min}$ and static time at $6 \mathrm{~min}$, for 3 cycles. Extracts were evaporated under a nitrogen stream (Zymark Turbovap II) down to a volume of $500 \mu \mathrm{l}$ and adjusted to $1 \mathrm{ml}$ with dichloromethane.

All samples and blanks were purified using a liquid chromatography purification procedure on SPE cartridge. This procedure was adapted from a protocol previously developed by Mazeas and Budzinski [34]. Organic extracts were eluted through an alumina SPE cartridge (Extract-Clean, Alltech, Templemars, France) with $9 \mathrm{ml}$ of dichloromethane in order to remove all macromolecules and polar interfering compounds. Then, a second purification on silica SPE cartridge (ExtractClean, Alltech, Templemars, France) was performed to separate the alkane fraction from the aromatic one in order to keep a clean GC/MS injection port. Alkanes were eluted with $1 \mathrm{ml}$ of n- 
pentane, then the aromatic compounds were collected with $9 \mathrm{ml}$ of a $(65 / 35, \mathrm{v} / \mathrm{v}) \mathrm{n}$ pentane/dichloromethane mixture. Finally, after reconcentration to dryness under an argon stream, residues were dissolved in $60 \mu \mathrm{l}$ of dichloromethane.

\subsection{Analysis}

NAPHs and OPAHs were analysed by GC/MS in the NICI mode. The column used for analyses was a 5\% phenyl-substituted methylpolysiloxane (DB-5MS, $30 \mathrm{~m} \times 0.25 \mathrm{~mm}$ I.D., $0.25 \mu \mathrm{m}$ film thickness, J\&W Scientific, USA). This column was adopted because of its capacity to well separate 6-nitrobenzo[a]pyrene from 1-nitrobenzo[e]pyrene $(\mathrm{m} / \mathrm{z}=297)$ [27], the first being a degradation product of benzo[a]pyrene. This latter PAHs being the reference compound used to evaluate the potential global PAHs toxicity, it is thus very important to quantify its nitrocongener, formed in the atmosphere and also perhaps during the sampling. On the other hand, it should be noted that separation of both isomers of nitrofluoranthene (2- and 3-nitrofluoranthene) will not be separated using this column. Analyses were performed using a Perkin-Elmer Clarus 500 gas chromatograph coupled to a Perkin-Elmer Turbomass Gold mass spectrometer. Program settings were as follows: cool splitless injection mode in order to not degrade NPAHs (injector temperature from $40{ }^{\circ} \mathrm{C}$ to $320{ }^{\circ} \mathrm{C}$ ), transfer line at $300{ }^{\circ} \mathrm{C}$ and constant gas flow through column of $1.2 \mathrm{ml} \mathrm{min}^{-1}$. The oven temperature program was the following: initial temperature at $60{ }^{\circ} \mathrm{C}$ for $2 \mathrm{~min} ; 45^{\circ} \mathrm{C} \mathrm{min}^{-1}$ to $150 \mathrm{C}$ for $5 \mathrm{~min}$; $5^{\circ} \mathrm{C} \min ^{-1}$ to $300{ }^{\circ} \mathrm{C}$ for $7 \mathrm{~min}$. Total run time was $46 \mathrm{~min}$. The volume injected varied from $0.5 \mu$ to $2 \mu$ l depending on the sample load. MS parameters are described below: source temperature $150{ }^{\circ} \mathrm{C}$, electron energy $45 \mathrm{eV}$; methane was used as the reagent gas for NICI. The mass spectrometer was run in selective ion monitoring mode (inter-channel delay: $0.01 \mathrm{~s}$; span: 0.1). Monitored ions and associated deuterium labelled NPAHs internal standards are shown in Table 1. 


\section{Results and discussion}

\subsection{Detection limits and recovery levels}

A total of 17 NPAHs and 9 OPAHs were separated and identified for quantification. Analytes were identified by comparison of retention times using standards. Quantification of NPAHs and OPAHs was based on a daily seven-point calibration curve $\left(\mathrm{r}^{2}>0.99\right)$. For instance, Figs. 1 and 2 present respectively, the reconstituted GC/MS total ion chromatogram for OPAHs and the GC/MS profiles of SIM of molecular ions in a particulate ambient air sample from the POVA research program.

The limits of detection (LODs), defined as the lowest concentration differing significantly from zero $(\mathrm{S} / \mathrm{N}=3)$, fall in the range value of $0.01-2.60 \mathrm{pg}$ and of $0.03-0.07 \mathrm{pg}$ for injected OPAHs (9fluorenone - 1,4-anthraquinone) and injected NPAHs (3-nitrophenanthrene - 6nitrobenzo[a]pyrene), respectively. The limits of quantification (LOQs), defined as the lowest concentration of the compound than can be determined $(\mathrm{S} / \mathrm{N}=10)$, fall in the range values of 0.03 $8.60 \mathrm{pg}$ of injected OPAHs and of 0.12-0.24 pg of injected NPAHs. Recovery factors (RFs) of the entire analytical procedure $(n=9)$ ranged, for NPAHs, from $14 \%$ for 1 -nitronaphthalene to $84 \%$ for 7-nitrobenz[a]anthracene and varied, for OPAHs, from 5\% for 1-naphthaldehyde to $83 \%$ for benzo[b]fluorenone. Results were corrected according to these recovery factors. Recoveries were strongly dependent on the solvent mixture used in the second step of the purification procedure. Finally, the mixing ratio used was the best compromise found to give acceptable recoveries for both NPAHs and OPAHs. Recoveries for the most volatile compounds (1-nitronaphtalene, 2nitronaphthalene and 1-naphthaldehyde) were relatively poor $(\mathrm{RFs}<50 \%)$. However, taking into account the lack of information for these three compounds in ambient air, results were considered as preliminary but interesting as they provide an order of magnitude of their concentrations in the reference material and in the ambient air samples. 


\subsection{OPAHs concentrations in air particulate reference material}

The quantitative results concerning OPAHs measured by GC/NICI-MS in SRM 1649a (urban dust) are listed in Table 2. Concentrations measured for the same compounds in previous studies are also reported in the same Table. Excluding the values for 9-fluorenone and 9,10-anthraquinone from Fernandez and Bayona [28], OPAHs concentrations measured in this work are in the same order of magnitude than most previously reported studies: Values given for instance for 9,10anthraquinone by Durant et al. [21] and Cho et al. [29] are very close to those measured in this work. 1,4-anthraquinone is the only compound that has not been detected in this material and benz[a]anthracen-7,12-dione appears to be the most abundant OPAHs.

\subsection{NPAHs concentrations in air particulate reference material}

Results for selected NPAHs in SRM 1649a (urban dust) measured in this study and those previously reported in the literature are compared in Table 3. Concentration values measured in this study are generally in good agreement within a range of 8-45\% (excluding Environment Canada data). The agreement for other compounds like 2-nitropyrene, 7-nitrobenz[a]anthracene and 6nitrochrysene, is less obvious (65-215\%).

\subsection{Application to ambient air samples}

The proposed method was applied for the analysis of OPAHs and NPAHs in ambient air samples collected during the POVA research program. As an example, atmospheric concentrations measured during the Winter 2002-2003 (from 01/24/03 to 01/30/03) at a rural site in the Maurienne valley (at Sollières, 1373 m) are presented in Table 4.

Among all the 17 NPAHs and 9 OPAHs measured, only the 1,4-anthraquinone was not detected in the particulate phase. Due to the very low ambient temperature during the sampling [average $\mathrm{T}^{\circ} \mathrm{C}$ 
$( \pm 1 \sigma)=-4.3( \pm 3.7)]$, the heaviest NPAHs (from 6-nitrochrysene to 6-nitrobenzo[a]pyrene) were not detected in the gas phase (neither 2-nitrofluorene and 1,4-anthraquinone). OPAHs and NPAHs with less than two aromatic cycles are principally present in the gas phase or partitioned between both phases (about 85\% in the gas phase for 1-naphthaldehyde, 1- and 2-nitronaphthalene and about only $45 \%$ for 9-fluorenone).

9,10-Anthraquinone and 9-fluorenone are the prevalent OPAHs in the particulate phase. 9nitroanthracene is the predominant NPAHs in the particles following by the 3+2-nitrofluoranthene and the 2-nitropyrene. This latter compound is a gas-phase reaction product commonly used as a tracer of atmospheric photochemical reaction [36-38]. The abundance of this compound, combined with the low concentration of 1-nitropyrene (direct emissions tracer [36-38]), indicates a large distance from the pollution sources.

Due to a lack of data in the literature, no direct comparison of the average concentration levels for all the OPAHs and NPAHs quantified in this work has been possible (same sampling season and similar sampling site characteristics). Nevertheless, concentrations of individual OPAHs and NPAHs such as 9,10-anthraquinone, 9-fluorenone, 1- and 2-nitropyrene have been compared with those measured in few previous other studies.

Considering the site of Sollières, which is a rural site, NPAHs and OPAHs average concentration levels observed are relatively important. In the Winter period, similar levels of 9-fluorenone (6.90 ng $\mathrm{m}^{-3}$ ), found in both gas and particulate phases in Minneapolis, and of 9,10-anthraquinone (1.0 pg $\mathrm{m}^{-3}$ ), measured in particulate matter samples collected in Alger, were reported in references [39] and [40], respectively. Comparable levels of 2-nitropyrene were also reported, during the Winter period, in big urban areas like Napoli $\left(60.0 \mathrm{pg} \mathrm{m}^{-3}\right)$ and São Paulo (42 $\left.\mathrm{pg} \mathrm{m}^{-3}\right)$ [36, 41]. Considering the distance from combustion sources, levels of 1-nitropyrene are about 10 times lower than those measured in urban sites (Napoli: $99.0 \mathrm{pg} \mathrm{m}^{-3}$, São Paulo: $99.0 \mathrm{pg} \mathrm{m}^{-3}$, Firenze: $130.0 \mathrm{pg} \mathrm{m}^{-3}$, Birmingham: 90.0 pg m$^{-3}$ ) [36, 41-43]. 
Fig. 3 shows the weekly variations of $\Sigma$ PAHp, $\Sigma$ OPAHp and $\Sigma$ NPAHp defined as the sum of the concentrations of PAHs, OPAHs and NPAHs mainly present in the particulate phase. This may concern PAHs with more than 3 aromatic cycles (from benz[a]anthracene to indeno[1,2,3cd]pyrene) and NPAHs or OHAPs with more than 2 rings. During the sampling week, three successive meteorological events were encountered: an anticyclonic period, strong snowfalls, following by a new anticyclonic period. During anticyclonic periods, the total PAHs concentration has increased, probably due to an accumulation process. Then, the strong snowfall has induced a decrease of the total PAHs concentration by wet deposition. This hypothesis is in good agreement with the evolution of the amounts of $\mathrm{PM}_{10}$ aerosols followed during the same period at the same site. More, variations of $\Sigma$ OPAHp and $\Sigma$ NPAHp are consistent with the evolution of $\Sigma$ PAHp and of the $\mathrm{PM}_{10}$ and validate the quantification method used for these compounds present at low concentrations in ambient air samples.

\section{Conclusion}

An analytical method has been especially developed for the simultaneous determination of 17 NPAHs and 9 OPAHs at very low concentration levels. Despite the large differences between the NPAHs and OPAHs concentration ranges (one to two orders of magnitude), this method is easy to apply and allows a routine quantification of ambient air NPAHs and OPAHs within a single analysis.

Studying PAHs derivatives appears very important considering their high mutagen capacity and the possible underestimation of the effect of the PAHs chosen in Europe as a reference, namely the benzo[a]pyrene, which may be potentially chemically degraded during high-volume air sampling $[44,45]$.

The analytical procedure was applied to both gas and particulate samples collected during the POVA research program. Preliminary results obtained at Sollières show a good correlation between 
primarily or secondary compounds and the characteristics of the rural sampling site. Measurements obtained for both NPAHs and OPAHs and resulting from the POVA campaigns carried out after the reopening of the "Tunnel du Mont Blanc" to the international traffic (Winter 2002-2003 and Summer 2003 campaigns) will be published in a future paper.

\section{Acknowledgements}

The authors wish to thank the French Ministry of Ecology and Sustainable Development (MEDD) and the ADEME agency for financial support. A.A. wishes to thank Yoann Fagault for his greeting in his laboratory, Karine Moirez for PAHs analysis, Amandine Fievet for PAHs sampling, and finally Jean-Luc Jaffrezo and all the POVA team.

\section{References}

[1] IARC, Overall evaluations of carcinogenicity an updating of IARC monographs, Lyon, 1987.

[2] L. H. Keith, W. A. Telliard, Environ. Sci. Technol. 13 (1979) 416.

[3] European Official Journal L23, 26/1/2005, p3.

[4] J. Arey, B. Zielinska, R. Atkinson, A.M. Winer, T. Ramdhal, J.N. Pitts Jr, Atmos. Environ. 20 (1986) 2239.

[5] R. Atkinson, S.M. Aschmann, J. Arey, P.L. Carter, Int. J. Chem. Kinet. 21 (1989) 801.

[6] R. Atkinson, S.M. Aschmann, J. Arey, B. Zielinska, D. Schuetzle, Atmos. Environ. 23 (1989) 2679.

[7] R. Atkinson, J. Arey, B. Zielinska, S.M. Aschmann, Int. J. Chem. Kinet. 22 (1990) 999.

[8] R. Atkinson, J. Arey, Environ. Health Perspect. 102 (1994) 117.

[9]D. Helmig, W.P. Harger, Sci Total Environ 148 (1994) 11. 
[10] J. Sasaki, S.M. Aschmann, E.S.C. Kwok, R. Atkinson, J. Arey, Environ. Sci. Technol. 31 (1997) 3173.

[11] Environmental Health Criteria 229, Selected nitro- and nitro-oxy-polycyclic aromatic hydrocarbons. WHO library, available at http://whqlibdoc.who.int/ehc/WHO_EHC_229.pdf, 2003.

[12] J.T. Barbas, M.E. Sigman, R. Dabestani, Environ. Sci. Technol. 30 (1996) 1776.

[13] J.O. Allen, N.M. Dookeran, K. Taghizadeh, A.L. Lafleur, K.A. Smith, A.F. Sarofim, Environ. Sci. Technol. 31 (1997) 2064.

[14] D. Schuetzle, Environ. Health Perspect. 47 (1983) 65.

[15] T. Enya, H. Suzuki, T. Watanabe, T. Hirayama, Y. Hisamatsu, Environ. Sci. Technol. 31 (1997) 2772.

[16] M.P. Hannigan, G.R. Cass, B.W. Penman, C.L. Crespi, A.L. Lafleur, W.F. Busby Jr, W.G. Thilly, B.R.T. Simoneit, Environ. Sci. Technol. 32 (1998) 3502.

[17] J. Lewtas, M. Nishioka, B. Peterson, Int. J. Environ. Anal. Chem. 39 (1990) 245.

[18] B.J. Finlayson-Pitts, J.N. Pitts Jr, Atmospheric Chemistry: Fundamental and experimental techniques, Wiley-Interscience, 1986.

[19] B.J. Finlayson-Pitts, J.N. Pitts Jr, Chemistry of the upper and lower atmosphere, WileyInterscience, 2000.

[20] J.L. Durant, W.F. Busby Jr, A.L. Lafleur, B.W. Penman, C.L. Crespi, Mutat. Res. 371 (1996) 123.

[21] J.L. Durant, A.L. Lafleur, E.F. Plummer, K. Taghizadeh, W.F. Busby, W.G. Thilly, Environ. Sci. Technol. 32 (1998) 1894.

[22] N.K. Wilson, T.R. McCurdy, J.C. Chuang, Atmos. Environ. 29 (1995) 2575.

[23] E. Leoz-Garziandia, V. Tatry, P. Carlier, Polycyclic Aromat. Compd. 20 (2000) 245.

[24] J. Schnelle-Kreis, I. Gebefugi, G. Welzl, T. Jaensch, A. Kettrup, Atmos. Environ. 35 (2001) 71. 
[25] C. Chiu, W. Miles, Polycyclic Aromat. Compd. 9 (1996) 307.

[26] D.Z. Bezabeh, H.A. Bamford, M.M. Schantz, S.A. Wise, Anal. Bioanal. Chem. 375 (2003) 381.

[27] H.A. Bamford, D.Z. Bezabeh, M.M. Schantz, S.A. Wise, J.E. Baker, Chemosphere. 50 (2003) 575.

[28] P. Fernandez, J.M. Bayona, J. Chromatogr. 625 (1992) 141.

[29] A.K. Cho, E. Di Stefano, Y. You, C.E. Rodriguez, D.A. Schmitz, Y. Kumagai, A.H. Miguel, A. Eiguren-Fernandez, T. Kobayashi, E. Avol, J.R. Froines, Aerosol Sci. Technol. 38 (2004) 68.

[30] Certificate of analysis, Standard Reference Material (SRM) 1649a, Urban Dust, National Institute of Standards and Technology (NIST), Gaithersburg, MD, 2001.

[31] D.L. Poster, M.M. Schantz, S.A. Wise, M.G. Vangel, Fresenius J. Anal. Chem. 363 (1999) 380.

[32] J.-L. Jaffrezo, A. Albinet, G. Aymoz, J.-L. Besombes, B. Bonsang, G. Brulfert, D. Chapuis, P. Chazette, C. Chemel, J.-P. Chollet, A. Colomb, P. Couvert, J. Cozic, E. Fréjafon, S. Geffroy, R. Greenwald, V. Jacob, C. Jambert, B. Jouve, E. Leoz-Garziandia, N. Marchand, P. Masclet, P.E. Perros, J. Rimetz, H. Villard, submitted for publication in Atmos. Chem. Phys (January 2005).

[33] A. Albinet, E. Leoz-Garziandia, J.-L. Besombes, N. Marchand, J.-L. Jaffrezo, in preparation for Atmos. Environ.

[34] L. Mazeas, H. Budzinski, Int. J. Environ. Anal. Chem. 82 (2002) 157.

[35] M.M. Schantz, S.A. Wise, J. Lewtas, Intercomparison exercise program for organic contaminants in $\mathrm{PM}_{2.5}$ air particulate matter: description and results for intercomparison exercise I. NIST Internal Report, Gaithersburg, MD, 2003.

[36] P. Ciccioli, A. Cecinato, E. Brancaleoni, F. Massimiliano, P. Zacchei, A.H. Miguel, P.C. Vasconcellos, J. Geophys. Res. 101 (1996) 19567.

[37] A. Cecinato, R. Mabilia, F. Marino, Atmos. Environ. 34 (2000) 5061. 
[38] A. Feilberg, M.W. B. Poulsen, T. Nielsen, Henrik Skov, Atmos. Environ. 35 (2001) 353.

[39] S.B. Hawthorne, D.J. Miller, J.J. Langenfeld, M.S. Krieger, Environ. Sci. Technol. 26 (1992) 2251.

[40] N. Yassaa, B.Y. Meklati, A. Cecinato, F. Marino, Environ. Sci. Technol. 35 (2001) 306.

[41] P. Ciccioli, A. Cecinato, E. Brancaleoni, M. Frattoni, P. Zacchei, P. De Castro Vasconcellos, Ann. Chim. 85 (1995) 455.

[42] M. Berlincioni, G. Croce, F. Ferri, N. Iacovella, C. La Rocca, M. Lolini, A. Megli, M. Pupp, L. Rizzi, L. Turrio Baldassarri, A. di Domenico, Fresenius Environ. Bull. 4 (1995) 169.

[43] M. Dimashki, S. Harrad, R.M. Harrison, Atmos. Environ. 34 (2000) 2459.

[44] M. Tsapakis, E.G. Stephanou, Atmos. Environ. 37 (2003) 4935.

[45] M. Goriaux, B. Jourdain, H. Wortham, B. Temine, J.-L. Besombes, N. Marchand, A. Albinet, E. Leoz-Garziandia, submitted for publication in Environ. Sci. Technol (February 2006). 
Table 1

Selected ion monitoring conditions for OPAHs and NPAHs

\begin{tabular}{|c|c|c|c|c|c|}
\hline Compound & $\begin{array}{l}\text { Monitored } \\
\text { ions }(\mathbf{m} / \mathbf{z})\end{array}$ & $\begin{array}{l}\text { Dwell } \\
\text { time (s) }\end{array}$ & $\begin{array}{c}\text { Labelled NPAHs internal } \\
\text { standard }\end{array}$ & $\begin{array}{l}\text { Monitored } \\
\text { ions }(\mathbf{m} / \mathbf{z})\end{array}$ & $\begin{array}{l}\text { Dwell } \\
\text { time (s) }\end{array}$ \\
\hline \multicolumn{6}{|c|}{ OPAHs } \\
\hline 1-Naphthaldehyde & 156 & 0.08 & {$\left[{ }^{2} \mathrm{H}_{9}\right] 1$-nitronaphthalene } & 180 & 0.04 \\
\hline 9-Fluorenone & 180 & 0.04 & {$\left[{ }^{2} \mathrm{H}_{9}\right] 1$-nitronaphthalene } & 180 & 0.04 \\
\hline 9-Phenanthrencarboxaldehyde & 206 & 0.08 & {$\left[{ }^{2} \mathrm{H}_{9}\right] 2$-nitrofluorene } & 220 & 0.08 \\
\hline 9,10-Anthraquinone & 208 & 0.04 & {$\left[{ }^{2} \mathrm{H}_{9}\right] 2$-nitrofluorene } & 220 & 0.08 \\
\hline 1,4-Anthraquinone & 208 & 0.04 & {$\left[{ }^{2} \mathrm{H}_{9}\right] 2$-nitrofluorene } & 220 & 0.08 \\
\hline Benzo[a]fluorenone & 230 & 0.04 & {$\left[{ }^{2} \mathrm{H}_{9}\right] 3$-nitrofluoranthene } & 256 & 0.08 \\
\hline Benzo[b]fluorenone & 230 & 0.04 & {$\left[{ }^{2} \mathrm{H}_{9}\right] 3$-nitrofluoranthene } & 256 & 0.08 \\
\hline Benzanthrone & 230 & 0.04 & {$\left[{ }^{2} \mathrm{H}_{9}\right] 3$-nitrofluoranthene } & 256 & 0.08 \\
\hline Benz[a]anthracen-7,12-dione & 258 & 0.08 & {$\left[{ }^{2} \mathrm{H}_{9}\right] 3$-nitrofluoranthene } & 256 & 0.08 \\
\hline \multicolumn{6}{|c|}{ NPAHs } \\
\hline 1-Nitronaphthalene & 173 & 0.08 & {$\left[{ }^{2} \mathrm{H}_{9}\right] 1$-nitronaphthalene } & 180 & 0.04 \\
\hline 2-Nitronaphthalene & 173 & 0.08 & {$\left[{ }^{2} \mathrm{H}_{9}\right] 1$-nitronaphthalene } & 180 & 0.04 \\
\hline 2-Nitrofluorene & 211 & 0.08 & {$\left[{ }^{2} \mathrm{H}_{9}\right] 2$-nitrofluorene } & 220 & 0.08 \\
\hline 9-Nitroanthracene & 223 & 0.04 & {$\left[{ }^{2} \mathrm{H}_{9}\right] 2$-nitrofluorene } & 220 & 0.08 \\
\hline 9-Nitrophenanthrene & 223 & 0.04 & {$\left[{ }^{2} \mathrm{H}_{9}\right] 2$-nitrofluorene } & 220 & 0.08 \\
\hline 3-Nitrophenanthrene & 223 & 0.04 & {$\left[{ }^{2} \mathrm{H}_{9}\right] 2$-nitrofluorene } & 220 & 0.08 \\
\hline 3+2-Nitrofluoranthene* & 247 & 0.08 & {$\left[{ }^{2} \mathrm{H}_{9}\right] 3$-nitrofluoranthene } & 256 & 0.08 \\
\hline 4-Nitropyrene & 247 & 0.08 & {$\left[{ }^{2} \mathrm{H}_{9}\right] 3$-nitrofluoranthene } & 256 & 0.08 \\
\hline 1-Nitropyrene & 247 & 0.08 & {$\left[{ }^{2} \mathrm{H}_{9}\right] 3$-nitrofluoranthene } & 256 & 0.08 \\
\hline 2-Nitropyrene & 247 & 0.08 & {$\left[{ }^{2} \mathrm{H}_{9}\right] 3$-nitrofluoranthene } & 256 & 0.08 \\
\hline 7-Nitrobenz[a]anthracene & 273 & 0.08 & {$\left[{ }^{2} \mathrm{H}_{9}\right] 6$-nitrochrysene } & 284 & 0.08 \\
\hline 6-Nitrochrysene & 273 & 0.08 & {$\left[{ }^{2} \mathrm{H}_{9}\right] 6$-nitrochrysene } & 284 & 0.08 \\
\hline 1,3-Dinitropyrene & 292 & 0.04 & {$\left[{ }^{2} \mathrm{H}_{9}\right] 6$-nitrochrysene } & 284 & 0.08 \\
\hline 1,6-Dinitropyrene & 292 & 0.04 & {$\left[{ }^{2} \mathrm{H}_{9}\right] 6$-nitrochrysene } & 284 & 0.08 \\
\hline 1,8-Dinitropyrene & 292 & 0.04 & {$\left[{ }^{2} \mathrm{H}_{9}\right] 6$-nitrochrysene } & 284 & 0.08 \\
\hline 6-Nitrobenzo[a]pyrene & 297 & 0.08 & {$\left[{ }^{2} \mathrm{H}_{9}\right] 6$-nitrochrysene } & 284 & 0.08 \\
\hline
\end{tabular}

* the separation of these two isomers could not be achieved on the 5\% phenyl-substituted methylpolysiloxane phase. 
Table 2

OPAHs concentrations (ng g ${ }^{-1}$ ) in SRM 1649a (urban dust)

\begin{tabular}{|c|c|c|c|c|}
\hline OPAHs & This work ${ }^{a}$ & Fernandez and Bayona, $1992^{b}$ & Durant et al.,1998 & Cho et al., $2004^{\mathrm{d}}$ \\
\hline 1-Naphthaldehyde & 199 (59)* & - & - & - \\
\hline 9-Fluorenone & 1110 (139) & $300(30)$ & $1600(110)$ & - \\
\hline 9-Phenanthrencarboxaldehyde & 247 (33) & - & - & - \\
\hline 9,10-Anthraquinone & $2238(363)$ & $220(40)$ & $2700(120)$ & $2030(192)$ \\
\hline 1,4-Anthraquinone & $\mathrm{nd}^{* *}$ & - & - & - \\
\hline Benzo[a]fluorenone & 3512 (284) & $1890(300)$ & $1900(210)$ & - \\
\hline Benzo[b]fluorenone & $4845(812)$ & $1570(20)$ & $5010(470)$ & - \\
\hline Benzanthrone & $3715(872)$ & $1310(20)$ & $4500(340)$ & - \\
\hline Benz[a]anthracen-7,12-dione & 8459 (797) & $7465(1100)$ & $2400(250)$ & - \\
\hline
\end{tabular}

* mean concentration (standard deviation).

** not detected.

${ }^{\text {a }}$ GC/NICI-MS (5\% phenyl phase), $n=6$.

${ }^{\text {b }}$ OPAHs values reported in [28], using GC/EI-MS (5\% phenyl phase) after fractionation by GPC (gel permeation chromatography) and NP-LC (normal phase liquid chromatography), n=1.

c OPAHs values reported in [21], using GC/EI-MS (5\% phenyl phase) after fractionation by gravity column chromatography and HPLC (high performance liquid chromatography), $n=1$ (3 injections).

${ }^{\mathrm{d}}$ OPAHs values reported in [29], using GC/EI-MS (5\% phenyl phase) after derivatization, $\mathrm{n}=12$. 
Table 3

NPAHs concentrations (ng g ${ }^{-1}$ ) in SRM 1649a (urban dust)

\begin{tabular}{|c|c|c|c|c|c|}
\hline \multirow[b]{2}{*}{ NPAHs } & \multirow[b]{2}{*}{ This work $^{\mathrm{a}}$} & \multirow[b]{2}{*}{ Bamford et al.,2003 } & \multirow[b]{2}{*}{$\begin{array}{l}\text { Chiu and } \\
\text { Miles,1996 }^{\mathrm{c}}\end{array}$} & \multicolumn{2}{|c|}{ Intercomparison exercise study } \\
\hline & & & & NIST $^{d}$ & $\begin{array}{c}\text { Environment } \\
\text { Canada }^{e}\end{array}$ \\
\hline 1-Nitronaphthalene & $12.5(2.6)^{*}$ & $6.8(0.3)$ & - & - & - \\
\hline 2-Nitronaphthalene & $12.0(2.4)$ & $10.0(0.5)$ & - & - & - \\
\hline 2-Nitrofluorene & $<0.4$ & $<5$ & $<2$ & - & - \\
\hline 9-Nitroanthracene & $39.1(4.2)$ & $35.9(0.6)$ & $34.0(1.0)$ & $33.9(0.9)$ & $6.4(0.9)$ \\
\hline 9-Nitrophenanthrene & $1.9(0.5)$ & $1.7(0.1)$ & $<2$ & - & - \\
\hline 3-Nitrophenanthrene & $34.0(3.4)$ & $22.0(0.6)$ & - & - & - \\
\hline 3+2-Nitrofluoranthene* & $316.1(47.4)$ & $286.5(32.8)$ & $315.0(29.0)$ & $334.8(15.8)$ & $225.0(20.0)$ \\
\hline 4-Nitropyrene & $6.0(0.9)$ & $5.5(0.6)$ & - & - & - \\
\hline 1-Nitropyrene & $104.5(6.4)$ & $71.5(5.1)$ & $78.0(8.0)$ & 79.5 (3.5) & $60.8(1.1)$ \\
\hline 2-Nitropyrene & $190.0(51.4)$ & $24.4(4.0)$ & - & - & - \\
\hline 7-Nitrobenz[a]anthracene & $11.1(7.2)$ & $35.1(3.6)$ & $25.0(1.0)$ & $29.5(0.7)$ & $19.3(0.9)$ \\
\hline 6-Nitrochrysene & $1.8(0.3)$ & $4.4(0.2)$ & $3.0(0.6)$ & $<5$ & $3.9(0.1)$ \\
\hline 1,3-Dinitropyrene & $<4$ & $<2$ & $<10$ & - & - \\
\hline 1,6-Dinitropyrene & $<3$ & $<4$ & $<10$ & - & - \\
\hline 1,8-Dinitropyrene & $<4$ & $<2$ & $<10$ & - & - \\
\hline 6-Nitrobenzo[a]pyrene & $25.0(6.7)$ & $<40$ & $<0.8$ & $<5$ & $122.0(9.0)$ \\
\hline
\end{tabular}

* mean concentration (standard deviation).

${ }^{\mathrm{a}} \mathrm{GC} / \mathrm{NICI}-\mathrm{MS}$ (5\% phenyl phase), $\mathrm{n}=6$.

${ }^{\mathrm{b}}$ NPAHs values reported in [27], using GC/ NICI-MS (50\% phenyl phase), $\mathrm{n}=3$.

${ }^{\mathrm{c}} \mathrm{NPAHs}$ values reported in [25], using GC/HRMS (high resolution mass spectrometry) (5\% phenyl phase), $\mathrm{n}=3$.

${ }^{\mathrm{d}}$ NPAHs values reported by NIST [35] using GC/MS (50\% phenyl phase), $\mathrm{n}=3$.

${ }^{\text {e}} \mathrm{NPAHs}$ values reported in [35], using GC/MS (5\% phenyl phase), $\mathrm{n}=3$. 


\section{Table 4}

Average atmospheric OPAHs $\left(\mathrm{ng} \mathrm{m}^{-3}\right)$ and NPAHs $\left(\mathrm{pg} \mathrm{m}^{-3}\right)$ concentrations at Sollières (rural site, 1373 m, Maurienne Valley, 7 sampling days of 12 h, Winter 2002-2003, n=13)

\begin{tabular}{|c|c|c|}
\hline Compound & Particulate phase & Gas phase \\
\hline \multicolumn{3}{|c|}{ OPAHs } \\
\hline 1-Naphthaldehyde & $0.13(0.00-0.52)^{*}$ & $1.43(0.00-4.42)$ \\
\hline 9-Fluorenone & $1.38(0.35-4.72)$ & $1.23(0.00-5.06)$ \\
\hline 9-Phenanthrencarboxaldehyde & $0.15(0.02-0.38)$ & $0.00(0.00-0.00)$ \\
\hline 9,10-Anthraquinone & $2.18(0.15$ - 9.93) & $0.01(0.00-0.06)$ \\
\hline 1,4-Anthraquinone & nd** & nd \\
\hline Benzo[a]fluorenone & $0.60(0.03-3.69)$ & $0.00(0.00-0.00)$ \\
\hline Benzo[b]fluorenone & $0.56(0.02-3.58)$ & $0.00(0.00-0.00)$ \\
\hline Benzanthrone & $0.46(0.02-2.97)$ & $0.00(0.00-0.00)$ \\
\hline Benz[a]anthracen-7,12-dione & $0.42(0.03-3.03)$ & $0.00(0.00-0.00)$ \\
\hline \multicolumn{3}{|c|}{ NPAHs } \\
\hline 1-Nitronaphthalene & $3.8(0.0-12.2)$ & $22.0(0.0-60.4)$ \\
\hline 2-Nitronaphthalene & $1.8(0.5-3.2)$ & $14.7(0.0-33.6)$ \\
\hline 2-Nitrofluorene & $0.2(0.0-2.0)$ & nd \\
\hline 9-Nitroanthracene & $105.5(2.5-626.5)$ & $2.1(0.0-17.8)$ \\
\hline 9-Nitrophenanthrene & $0.4(0.0-0.8)$ & $0.0(0.0-0.1)$ \\
\hline 3-Nitrophenanthrene & $3.2(0.2-1.54)$ & $0.0(0.0-0.1)$ \\
\hline 3+2-Nitrofluoranthene* & $76.7(8.0-538.8)$ & $0.0(0.0-0.1)$ \\
\hline 4-Nitropyrene & $6.1(0.5-22.9)$ & $0.0(0.0-0.2)$ \\
\hline 1-Nitropyrene & $10.6(2.7-28.9)$ & $0.0(0.0-0.2)$ \\
\hline 2-Nitropyrene & $67.1(6.7-403.2)$ & $0.3(0.0-4.4)$ \\
\hline 7-Nitrobenz[a]anthracene & $15.3(0.0-154.1)$ & $0.0(0.0-0.5)$ \\
\hline 6-Nitrochrysene & $0.6(0.2-2.4)$ & nd \\
\hline 1,3-Dinitropyrene & $3.7(0.0-27.7)$ & nd \\
\hline 1,6-Dinitropyrene & $1.3(0.0-4.4)$ & nd \\
\hline 1,8-Dinitropyrene & $9.5(0.0-27.2)$ & nd \\
\hline 6-Nitrobenzo[a]pyrene & $8.6(0.0-93.4)$ & nd \\
\hline
\end{tabular}

* mean concentration (min - max).

** not detected. 


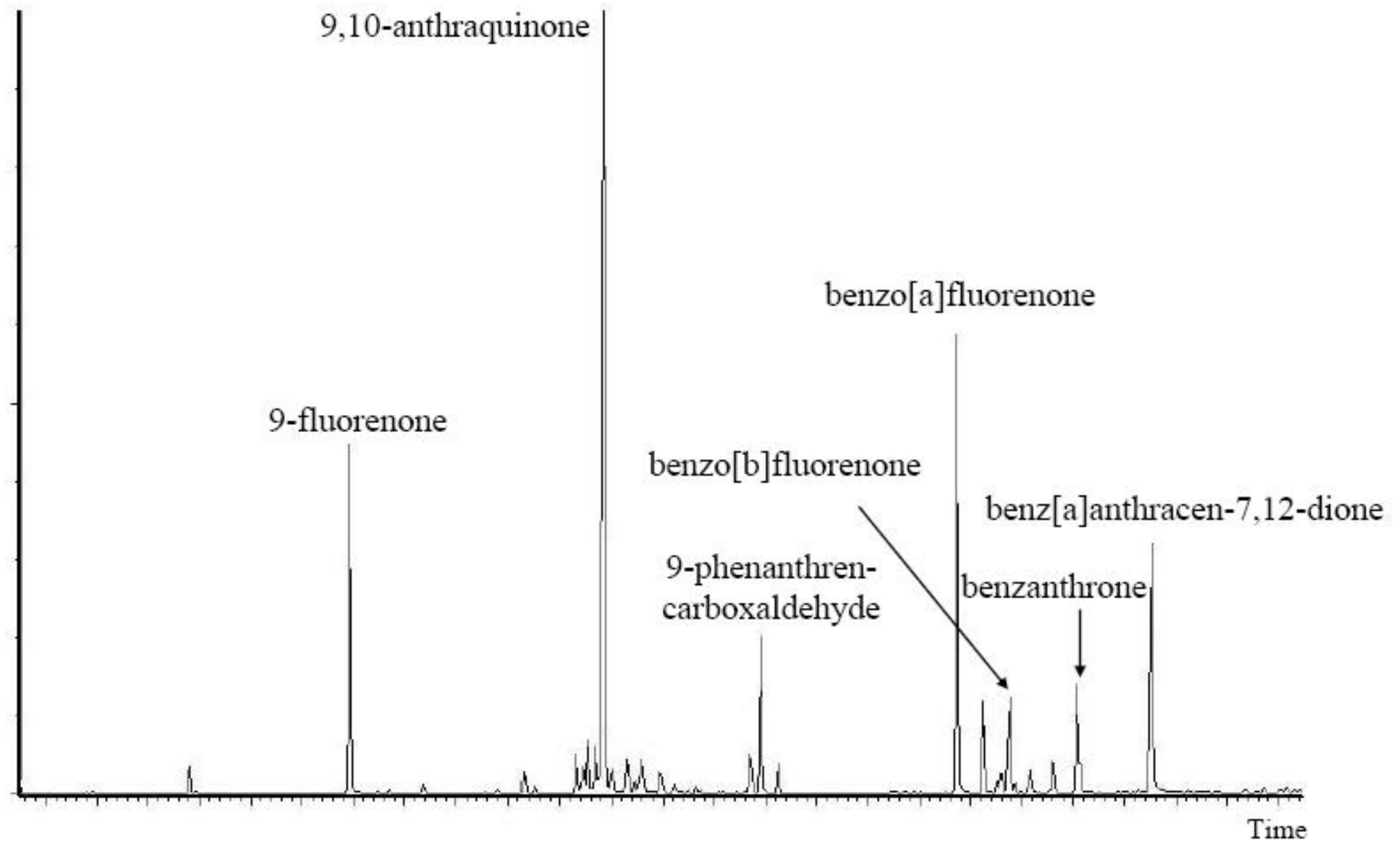




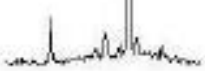

\section{$\mathrm{m} / \mathrm{z}=247$}

$\mathrm{m} / \mathrm{z}=223$
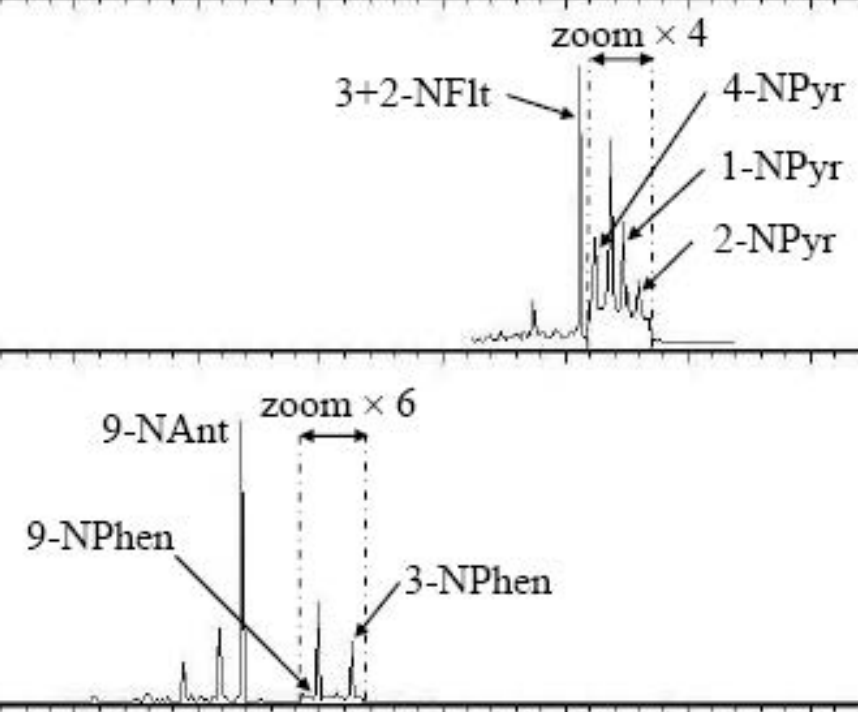


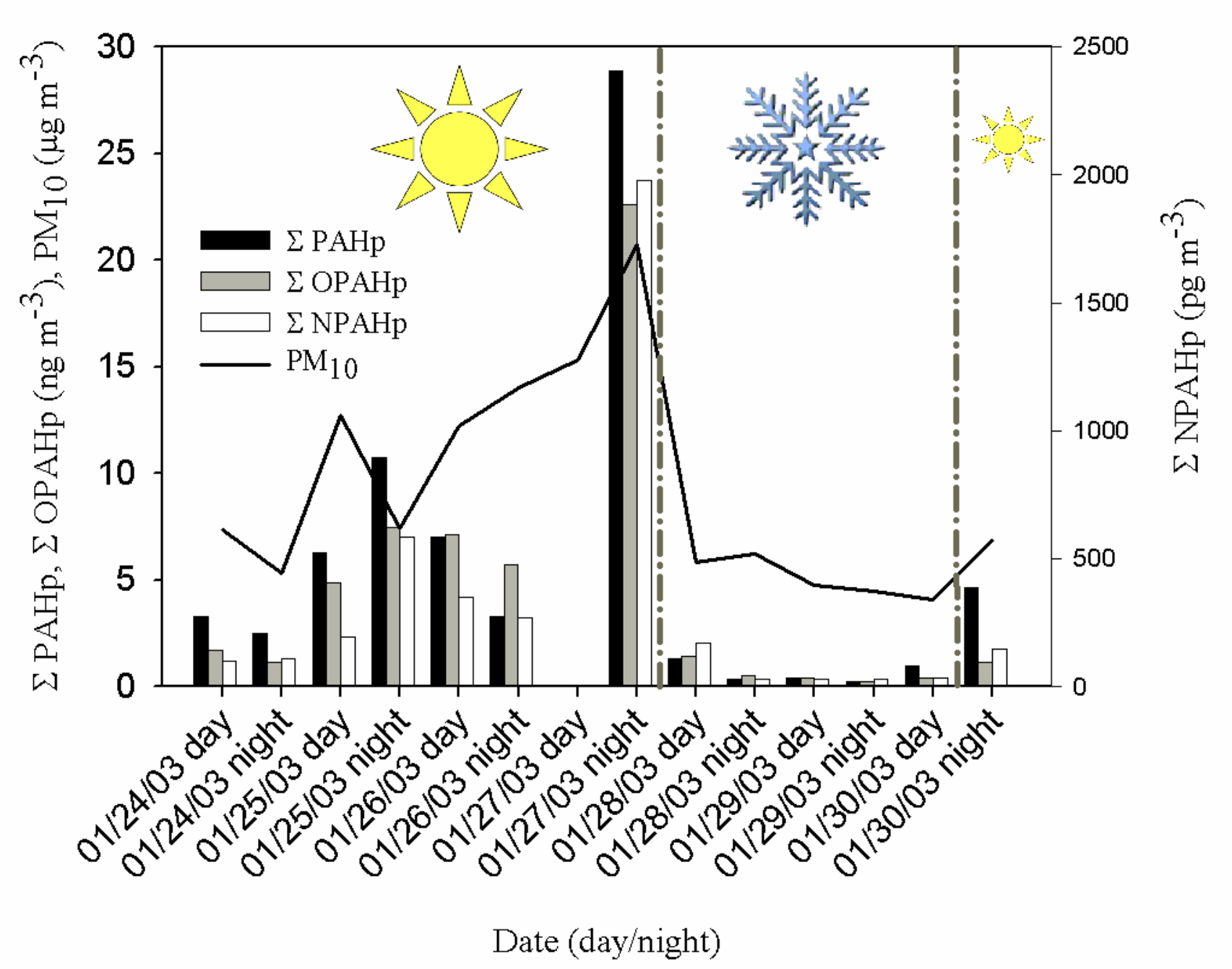

